\title{
Canadian practice assessment in chronic obstructive pulmonary disease: Respiratory specialist physician perception versus patient reality
}

\author{
Paul Hernandez MDCM FRCPC ${ }^{1}$, Meyer S Balter MD FRCPC FCCP², Jean Bourbeau MD FRCPC ${ }^{3}$, \\ Charles K Chan MD FRCPC FCCP FACP ${ }^{4}$, Darcy D Marciniuk MD FRCPC FCCP5, Shannon L Walker MD FRCPC ${ }^{6}$
}

\begin{abstract}
P Hernandez, MS Balter, J Bourbeau, CK Chan, DD Marciniuk, SL Walker. Canadian practice assessment in chronic obstructive pulmonary disease: Respiratory specialist physician perception versus patient reality. Can Respir J 2013;20(2):97-105.
\end{abstract}

INTRODUCTION: Chronic obstructive pulmonary disease (COPD) is a common respiratory condition and the fourth leading cause of death in Canada. Optimal COPD management requires patients to participate in their care and physician knowledge of patients' perceptions of their disease. METHODS: A prospective study in which respiratory specialist physicians completed a practice assessment questionnaire and patient assessments for 15 to 20 consecutive patients with COPD. Patients also completed a questionnaire regarding their perceptions of COPD and its management.

RESULTS: A total of 58 respiratory specialist physicians from across Canada completed practice assessments and 931 patient assessments. A total of 640 patients with COPD (96\% with moderate, severe or very severe disease) completed questionnaires. Symptom burden was high and most patients had experienced a recent exacerbation. Potential COPD care gaps were identified with respect to appropriate medication prescription, lack of an action plan, and access to COPD educators and pulmonary rehabilitation. Perceived knowledge needs and gaps differed between physicians and patients.

CONCLUSIONS: Despite the dissemination of Canadian and international COPD clinical practice guidelines for more than a decade, potential care gaps remain among patients seen by respiratory specialist physicians. Differing perceptions regarding many aspects of COPD among physicians and patients may contribute to these care gaps.

Key Words: Care gaps; Clinical practice guidelines; COPD; Patient knowledge; Practice assessment; Survey

\section{L'évaluation des pratiques canadiennes en cas de maladie pulmonaire obstructive chronique : la perception du médecin spécialiste en pneumologie par rapport à la réalité du patient}

INTRODUCTION : La maladie pulmonaire obstructive chronique (MPOC), un trouble respiratoire courant, est la quatrième cause de décès en importance au Canada. Pour une prise en charge optimale de la MPOC, le patient doit participer aux soins et le médecin doit savoir comment le patient perçoit sa maladie.

MÉTHODOLOGIE : Étude prospective au cours de laquelle des médecins spécialistes en pneumologie ont répondu à un questionnaire d'évaluation de la pratique et ont évalué de 15 à 20 patients consécutifs atteints d'une MPOC. Les patients ont également rempli un questionnaire sur leurs perceptions de la MPOC et de sa prise en charge.

RÉSULTATS : Au total, 58 médecins spécialistes en pneumologie de partout au Canada ont rempli des évaluations de la pratique et 931 évaluations de patient. De plus, 640 patients ayant une MPOC (dont $96 \%$ avaient une maladie modérée, grave ou très grave) ont rempli les questionnaires. Le fardeau de la maladie était élevé, et la plupart des patients avaient subi une exacerbation récente. Les chercheurs ont constaté des lacunes potentielles sur le plan des soins pour ce qui est de la prescription pertinente de médicaments, de l'absence de plan d'action et de l'accès à des éducateurs en $\mathrm{MPOC}$ et à une réadaptation pulmonaire. Les médecins et les patients n'avaient pas la même perception des besoins et des lacunes en matière de savoir.

CONCLUSIONS : Malgré la diffusion de lignes de pratique clinique canadiennes et internationales sur la MPOC depuis plus d'une décennie, il reste encore d'éventuelles lacunes en matière de soins des patients traités par des médecins spécialistes en pneumologie. Des perceptions différentes des médecins et des patients à l'égard de nombreux aspects de la MPOC contribuent à ces lacunes.

psychosocial burden related to living with this disease. In general, respondents had poor knowledge about the causes of COPD and their role in its management, especially during exacerbations (7).

Optimal COPD management requires patients to participate in their care and physician knowledge of patients' perceptions of their disease. The purpose of the present study was to prospectively collect 'real world' data with respect to COPD practice patterns and perceptions among respiratory specialist physicians. A concurrent patient survey enabled comparison of perceptions of COPD between health care providers and their patients.

Over the past decade, a number of national and international clinical practice guidelines that provide clinicians with evidence-based recommendations for the diagnosis and treatment of COPD $(1,4,5)$ have been published. Despite the promulgation of these guidelines, significant care gaps have been reported in COPD management, particularly at the primary care level (6). A telephone survey of 389 individuals with self-reported COPD revealed substantial symptom and

\section{Study design and participants \\ METHODS}

The present prospective study was conducted between June 15 and October 15, 2010. Physicians were required to complete a structured

${ }^{1}$ Division of Respirology, Department of Medicine, QEII Health Sciences Centre, Dalhousie University, Halifax, Nova Scotia; ${ }^{2}$ Division of Respirology, Mount Sinai Hospital, University of Toronto, Toronto, Ontario; ${ }^{3}$ Respiratory Epidemiology and Clinical Research Unit, Montreal Chest Institute, McGill University, Montreal, Quebec; ${ }^{4}$ Department of Medicine, University Health Network, University of Toronto, Toronto, Ontario; ${ }^{5}$ Division of Respirology, Critical Care and Sleep Medicine, Royal University Hospital, University of Saskatchewan, Saskatoon,

Saskatchewan; ${ }^{6}$ Department of Medicine, Penticton Regional Hospital, Penticton, British Columbia

Correspondence: Dr Paul Hernandez, Room 4458, Halifax Infirmary, 1796 Summer Street, Halifax, Nova Scotia B3H 3A7.

Telephone 902-473-3698, fax 902-473-6202, e-mail paul.hernandez@cdha.nshealth.ca 
TABLE 1

Demographics of chronic obstructive pulmonary disease (COPD) patients

\begin{tabular}{|c|c|c|c|c|c|c|c|}
\hline \multirow[b]{2}{*}{ Patient type } & \multicolumn{2}{|c|}{ Sex } & \multirow{2}{*}{$\begin{array}{l}\text { Age, years, } \\
\text { mean }\end{array}$} & \multicolumn{3}{|c|}{ Smoking status } & \multirow{2}{*}{$\begin{array}{c}\text { Family history of } \\
\text { COPD }\end{array}$} \\
\hline & Male & Female & & Current & Former & Never & \\
\hline Existing $(\mathrm{n}=727)$ & 54 & 46 & 69 & 23 & 70 & 7 & 21 \\
\hline Specialist referral $(n=32)$ & 53 & 47 & 67 & 44 & 56 & 0 & 28 \\
\hline FP referral, suspected diagnosis $(n=69)$ & 52 & 48 & 67 & 42 & 52 & 6 & 32 \\
\hline
\end{tabular}

Data presented as \% unless otherwise indicated. FP Family practitioner

questionnaire (practice assessment) at study entry and a patient assessment for 15 to 20 consecutive patients with COPD seen during a regularly scheduled visit. These same patients were then invited to complete a separate study questionnaire. Patients and physicians were blinded to one anothers' responses. Neither group received financial compensation for their involvement in the present study. The questionnaires were developed by the study authors. Because the study was conducted at individual physician clinics across the country, it received research ethics approval from a central review board (Institutional Review Board Services, Aurora, Ontario).

The target recruitment population was general respiratory physicians, regionally distributed across Canada. Physicians whose practices focused in subspeciality areas of sleep medicine, asthma, transplant, pulmonary hypertension and critical care were excluded from the survey. Patients were recruited from the practices of the respiratory physicians during a regularly scheduled visit. Inclusion criteria were either a confirmed diagnosis of COPD based on the definition in the Canadian Thoracic Society (CTS) COPD guidelines (1) or a suspected diagnosis of COPD based on referral from a family practitioner (FP) or nonrespiratory physician specialist. Patients referred by another respiratory physician were excluded.

\section{Questionnaires}

Practice profile questionnaire: Physicians who consented to participate completed a one-time electronic questionnaire (practice profile) at the beginning of the study. The questionnaire contained 20 questions designed to collect data on the physician's practice profile (eg, type of practice, practice setting and referral population), characteristics of their COPD patients and physician perceptions of issues relevant to COPD (eg, how knowledgeable patients are about COPD, the effect of dyspnea on patients' daily lives, diurnal variability of patient symptoms and patient inhaler device technique). Additional details of the physician questionnaire can be found in Appendix A.

Patient questionnaire: Consecutive patients with COPD from each respiratory physician's practice were invited to complete an anonymous, paper-based questionnaire consisting of 18 questions. The responses were linked to a physician's practice but not to a specific patient. The questionnaire was designed to collect data regarding management of the COPD patient population (eg, participation in pulmonary rehabilitation programs and current medication) and also to identify patient perceptions of issues relevant to COPD such as symptoms, knowledge of disease and sources of education. Additional details regarding the patient questionnaire can be found in Appendix B.

COPD patient assessment: In addition to the patient and physician questionnaires, physicians recorded clinical observations and management details following the visit by their COPD patient. The patient assessment consisted of an electronic questionnaire of 33 questions, details of which can be found in Appendix C.

\section{RESULTS}

Of the 601 respiratory physicians in Canada, 58 participated in the present study $(9.7 \%)$, with good regional representation (eight practiced in British Colombia, four in Alberta, four in Saskatchewan/ Manitoba, 18 in Ontario, 18 in Quebec and six in Atlantic Canada). Of the 601 respiratory physicians in Canada, those known by the authors to have a practice profile meeting the exclusion criteria of the study were not invited to participate. All physicians completed practice assessment questionnaires and also completed 931 patient assessments. From among these 931 patients, 640 subsequently completed questionnaires, yielding a response rate of $69 \%$.

\section{Practice profiles of participating physicians}

Of the 58 participating respiratory physicians, 19 practiced in a university setting, six in a university/private practice setting and 33 in private practice (private clinic/community). The majority (64\%) of respiratory physicians reported actively following (seen in the past year) between 100 and 500 patients with COPD in their practice, $21 \%$ reported actively following $>500,12 \%$ actively followed $<100$ and $3 \%$ were unsure. Mean wait times for COPD patients were reported to be 10.1 weeks for the four western provinces $(n=16)$, seven weeks for Ontario $(n=18), 13$ weeks for Quebec $(n=18)$ and 10.8 weeks for Atlantic Canada $(n=6)$. The mean referral population size was estimated to be 700,000 for the four western provinces, 490,000 for Ontario, 680,000 for Quebec and 450,000 for Atlantic Canada.

The COPD clinical practice guidelines most frequently referred to by physicians were those produced by the CTS (91\%), the American Thoracic Society/European Respiratory Society (43\%) and the Global initiatitive for chronic Obstructive Lung Diseases (43\%). The CTS clinical practice guidelines recommend using the Medical Research Council (MRC) dyspnea scale in addition to spirometry to assess COPD severity; physicians reported using the MRC dyspnea scale always (43\%), frequently (31\%), rarely (24\%) and never (2\%) during office visits (1). Physical examination, including oxygen saturation, was routinely performed to assess new (100\%) and follow-up (98\%) patients. In new patients, other routine assessments included chest radiograph $(95 \%)$, full pulmonary function tests $(84 \%)$, spirometry $(81 \%)$ and arterial blood gas $(26 \%)$. In follow-up patient visits, spirometry was performed in $79 \%$ of patients, and chest radiographs and full pulmonary function tests were performed in $21 \%$ of patients. Arterial blood gas measurements were not performed.

\section{Patient demographics and clinical characteristics}

Demographic data of the COPD patients $(n=931)$ included in the present study are summarized in Table 1 . There was a significant number $(20 \%$ to $32 \%)$ of COPD patients who reported a positive family history of COPD, a high percentage of whom were current smokers, particularly among new referrals. The majority $(82 \%)$ of patients had comorbidities (hypertension [45\%], ischemic heart disease [26\%], osteoporosis [19\%], diabetes [17\%] and depression [15\%]). The mean number of comorbidities per patient was 2.7. Of the patients with comorbidities, $22 \%$ had one comorbidity, $24 \%$ had two, $16 \%$ had three and $20 \%$ had four or more. Based on CTS spirometric definitions of COPD severity, for patients with current spirometry values $(n=476)$, the majority were moderate or severe (mild, $n=20$ [4\%]; moderate, $\mathrm{n}=204$ [43\%]; severe, $\mathrm{n}=192$ [40\%]; very severe, $\mathrm{n}=60$ [13\%]) (1). The majority of patients were moderate using the MRC symptom-based disease severity classification (total $n=931$; no exertional dyspnea [MRC 1], $\mathrm{n}=50$ [5\%]; mild [MRC 2], $\mathrm{n}=220$ [24\%]; moderate [MRC 3 to 4], $\mathrm{n}=582$ [63\%]; and severe [MRC 5], $\mathrm{n}=79$ [8\%]).

\section{Patient visits}

Patients reported that they visited their respiratory physicians an average of 2.5 times per year $(12 \%<1$ time per year, $58 \%$ one to two time[s] per year; $25 \%$ three to six times per year; $3 \%$ six to 10 times per 
TABLE 2

Exacerbation frequency in past 12 months according to chronic obstructive pulmonary disease (COPD) severity, determined by spirometry-derived forced expiratory volume in $1 \mathrm{~s}$ values and Medical Research Council (MRC) dyspnea score

\begin{tabular}{|c|c|c|c|c|}
\hline \multirow[b]{2}{*}{ Exacerbation in past 12 months } & \multicolumn{4}{|c|}{ COPD severity according to spirometry } \\
\hline & Mild $(n=20)$ & Moderate $(n=204)$ & Severe $(n=192)$ & Very severe $(n=60)$ \\
\hline Yes & 40 & 46 & 67 & 67 \\
\hline \multirow[t]{2}{*}{ No } & 60 & 54 & 33 & 33 \\
\hline & \multicolumn{4}{|c|}{ COPD severity according to MRC dyspnea score } \\
\hline Exacerbation in past 12 months & MRC $1(n=50)$ & Mild (MRC 2) $(n=220)$ & Moderate (MRC 3-4) $(n=582)$ & Severe (MRC 5) $(n=79)$ \\
\hline Yes & 32 & 32 & 65 & 81 \\
\hline No & 68 & 68 & 35 & 19 \\
\hline
\end{tabular}

Data presented as \%

year, $2 \%>10$ times per year). According to physicians, the main reason for the patient visit on the day that the patient assessment questionnaire was completed was for a regular follow-up for COPD (71\%), shortness of breath (17\%), exacerbation (10\%) and cough (8\%).

\section{Symptoms}

Shortness of breath: impact on activities of daily living: Most patients indicated that shortness of breath negatively impacted their routine activities of daily living (eg, meal preparation, bathing, dressing) - rating the degree of impact as extreme (6\%), very much $(29 \%)$, moderate $(28 \%)$, a little (24\%) and not at all (13\%). There were slight differences regionally, with patients in Quebec indicating a slightly higher negative impact versus the other regions. Fifty-two per cent of patients reported that shortness of breath affected their activities of daily living every day or most days.

Sputum production: Sixty-five per cent of patients reported having a cough productive of sputum: daily in $44 \%$, most days in $10 \%$ and weekly in $11 \%$. Eighty per cent reported that their sputum was usually clear or white in colour, $17 \%$ reported coloured sputum and 3\% were uncertain of the colour.

Diurnal variability of symptoms: Perception of morning as the most challenging time of day for patients due to respiratory symptoms was similarly reported by patients $(n=635[33 \%])$ and physicians $(n=931[29 \%])$. Patients reported that their physicians asked them about diurnal variability of respiratory symptoms very often $(8 \%)$, often or sometimes $(50 \%)$, and rarely or never $(42 \%)$.

\section{COPD exacerbation frequency, severity and management}

Of the 931 patients assessed by physicians, 57\% ( $n=527)$ had experienced an exacerbation of COPD in the previous 12 months. The probability of experiencing an exacerbation increased with increasing COPD severity, regardless of whether it was determined using spirometry or MRC dyspnea score (Table 2). However, even among patients with mild disease, a minority reported a history of recent exacerbation. Exacerbation frequency was similar between follow-up COPD patients and new referrals. Among patients who experienced an exacerbation within the past 12 months, $58 \%$ were treated with an antibiotic, $52 \%$ with an increased dose or new prescription for oral or parenteral steroids, $41 \%$ with both antibiotics and oral steroids, 30\% visited an emergency department and 34\% were hospitalized. The likelihood of being treated with both antibiotics and systemic steroids increased with increasing COPD severity.

Sixty-one per cent of COPD patients reported that they had been taught to recognize the signs and symptoms of an exacerbation of COPD, most by their physician $(51 \%)$ and $20 \%$ by a COPD nurse educator (some reported being taught by both health care professionals); however, 39\% claimed that they had never been taught. Of 640 patients, 248 (39\%) reported having a COPD action plan; of these patients, 79\% reported having been provided with a written prescription for antibiotics and/or steroids, while only $52 \%$ reported having access to review their action plan with a COPD nurse educator. Access to a COPD nurse educator to review action plans varied considerably according to region: lowest in the four western provinces and Ontario, and highest in Quebec and Atlantic Canada.
TABLE 3

Current medications prescribed to patients with chronic obstructive pulmonary disease (COPD) according to disease severity determined by spirometry

\begin{tabular}{lrccc}
\hline & \multicolumn{4}{c}{ COPD severity according to spirometry } \\
\cline { 2 - 5 } Current medication & $\begin{array}{c}\text { Mild } \\
(\mathbf{n}=\mathbf{2 0})\end{array}$ & $\begin{array}{c}\text { Moderate } \\
(\mathbf{n}=\mathbf{2 0 4})\end{array}$ & $\begin{array}{c}\text { Severe } \\
(\mathbf{n}=\mathbf{1 9 2})\end{array}$ & $\begin{array}{c}\text { Very severe } \\
(\mathbf{n}=\mathbf{6 0})\end{array}$ \\
\hline Salbutamol (SABA) & 70 & 74 & 79 & 80 \\
Terbutaline (SABA) & 5 & 2 & 3 & 2 \\
Ipratropium (SAAC) & 10 & 13 & 8 & 3 \\
Tiotropium (LAAC) & 70 & 67 & 78 & 88 \\
Salmeterol (LABA) & 5 & 3 & 3 & 1 \\
Budesonide/formoterol & 25 & 22 & 29 & 18 \\
$\quad$ (ICS/LABA) & & & & \\
Fluticasone/salmeterol & 35 & 49 & 54 & 73 \\
$\quad$ (ICS/LABA) & & & & \\
Theophylline & 0 & 2 & 11 & 18 \\
Chronic antibiotics & 0 & 1 & 2 & 0 \\
Oral steroids & 5 & 2 & 4 & 8 \\
Other & 25 & 7 & 14 & 25 \\
None & 5 & 3 & 3 & 0 \\
\hline
\end{tabular}

Data presented as \%. ICS Inhaled corticosteroid; LAAC Long-acting anticholinergic; LABA Long-acting beta ${ }_{2}$-agonist; SAAC Short-acting anticholinergic; SABA Short-acting beta ${ }_{2}$-agonist

Regarding preventive measures for exacerbations, there was a higher rate of influenza vaccination in the past 12 months among existing patients who were followed in respiratory specialists' practices $(81 \%)$, compared with new patients referred by other specialists (68\%), referred by FPs in cases for which COPD was confirmed (76\%) and, especially, patients referred by FPs in cases for which COPD was only suspected (45\%). Pneumococcal vaccination rates were similarly highest among existing patients followed in respiratory specialists' practices $(70 \%)$ versus new patients coming from the three referral sources noted above $(50 \%, 53 \%$ and $30 \%$, respectively).

\section{Pharmacotherapy}

Current medications prescribed to patients according to COPD disease severity determined by spirometry or MRC dyspnea score are presented in Table 3 and Table 4, respectively. The majority of patients across the disease severity spectrum were prescribed a shortacting bronchodilator, most commonly salbutamol. The number of medications prescribed increased with disease severity, although a small percentage of patients with moderate to severe disease were on no medications for COPD. According to current CTS COPD clinical practice guideline recommendations, inhaled corticosteroid/long-acting beta-agonist (ICS/LABA) combination inhalers (ie, fluticasone/ salmeterol or budesonide/formoterol) were overprescribed in patients with mild disease. For patients with a history of one or more exacerbation and at least moderate severity COPD (ie, those at greatest risk for future exacerbations), only $34 \%$ were prescribed 'triple inhaled maintenance therapy': an ICS/LABA plus a long-acting anticholinergic, as recommended by the CTS COPD clinical practice guidelines. 
TABLE 4

Current medications prescribed to patients with chronic obstructive pulmonary disease (COPD) according to disease severity determined by Medical Research Council (MRC) dyspnea score

\begin{tabular}{|c|c|c|c|c|}
\hline \multirow[b]{2}{*}{ Current medication } & \multicolumn{4}{|c|}{ COPD severity according to MRC dyspnea score } \\
\hline & $\begin{array}{l}\text { MRC } 1 \\
(n=50)\end{array}$ & $\begin{array}{c}\text { Mild (MRC 2) } \\
(n=220)\end{array}$ & $\begin{array}{c}\text { Moderate } \\
\text { (MRC 3-4) } \\
(n=582)\end{array}$ & $\begin{array}{c}\text { Severe } \\
\text { (MRC 5) } \\
(n=79)\end{array}$ \\
\hline Salbutamol (SABA) & 66 & 74 & 78 & 81 \\
\hline Terbutaline (SABA) & 0 & 3 & 3 & 1 \\
\hline Ipratropium (SAAC) & 12 & 11 & 12 & 8 \\
\hline Tiotropium (LAAC) & 34 & 65 & 76 & 95 \\
\hline Salmeterol (LABA) & 2 & 1 & 4 & 2 \\
\hline $\begin{array}{l}\text { Budesonide/formoterol } \\
\text { (ICS/LABA) }\end{array}$ & 24 & 22 & 25 & 24 \\
\hline $\begin{array}{l}\text { Fluticasone/salmeterol } \\
\text { (ICS/LABA) }\end{array}$ & 26 & 49 & 53 & 72 \\
\hline Theophylline & 2 & 2 & 9 & 21 \\
\hline Chronic antibiotics & 2 & 1 & 1 & 2 \\
\hline Oral steroids & 0 & 4 & 4 & 16 \\
\hline Other & 6 & 7 & 12 & 21 \\
\hline None & 10 & 5 & 2 & 0 \\
\hline
\end{tabular}

Data presented as \%. ICS Inhaled corticosteroid; LAAC Long-acting anticholinergic; $L A B A$ Long-acting beta ${ }_{2}$-agonist; SAAC Short-acting anticholinergic; SABA Short-acting beta ${ }_{2}$-agonist

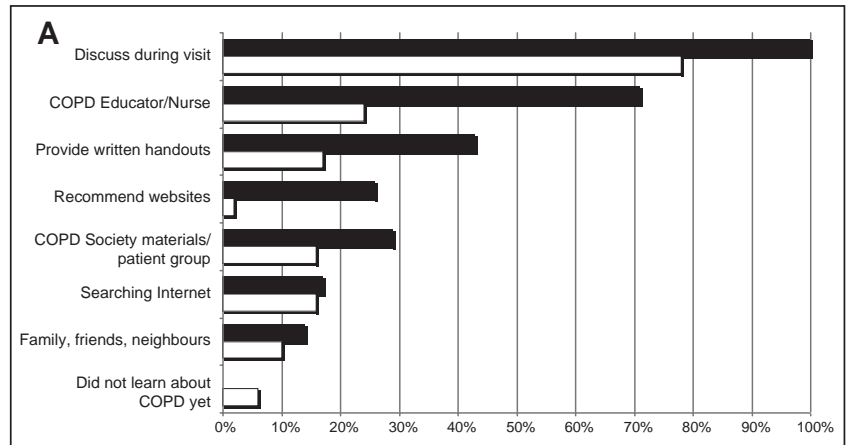

B

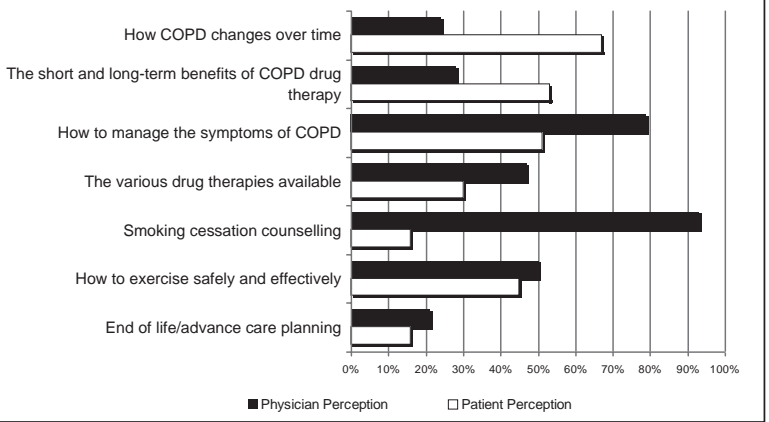

Figure 1) Patient and physician perception of chronic obstructive pulmonary disease (COPD) patient education sources (A) and priorities (B). A Physician question ( $n=58)$ : How do you educate your patients about COPD? Check all that apply (black bars). Patient question ( $n=644)$ : How do you educate yourself about COPD? Check all that apply (white bars). B Physician question $(n=58)$ : Select the top three areas where you think your patients would like to receive more information (black bars). Patient question $(n=644)$ : Select the top three areas where you would like to receive more information (white bars)

\section{Pulmonary rehabilitation}

Regarding pulmonary rehabilitation, $24 \%$ of patients responded that they had participated in such a program, $63 \%$ had not participated and

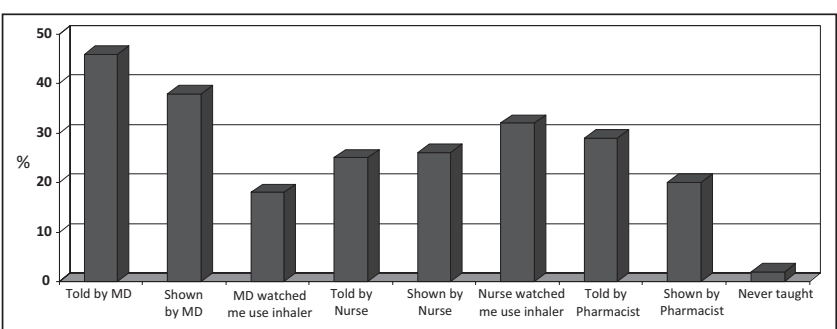

Figure 2) Patient education. Patient response regarding how and by whom they received instruction on proper inhaler technique. MD Physician

$13 \%$ were not sure what 'pulmonary rehabilitation' was. Of the patients who participated ( $n=132$ ), $41 \%$ had very severe COPD, $30 \%$ had severe COPD, 23\% had moderate COPD and 29\% had mild COPD. The majority of patients $(68 \%)$ had been referred to pulmonary rehabilitation by their respiratory specialist physician, $20 \%$ by their family physician, $11 \%$ by a respiratory therapist, $5 \%$ by a nurse, $2 \%$ by another health care professional and $1 \%$ by another patient.

\section{Patient education}

In terms of how patients were educated about COPD, patients and physicians both reported that COPD education occurred most often during clinic visits (Figure 1A). There were wide gaps in perceived roles of other sources of COPD patient education (eg, COPD nurse educator, written material, handouts, websites) between physicians and patients (Figure 1B). Seventy-one per cent of physicians indicated that they also educated their patients through a COPD educator; however, only $24 \%$ of patients availed themselves of this educational resource (Figure 1A). Other educational tools were used even less by patients. The majority of respiratory physicians (70\%) indicated that their patients had access to a COPD educator, with the highest percentage in Quebec and the lowest in the Atlantic provinces.

Although both groups agreed that COPD patient education was important, priorities differed between patients and physicians. The top three educational priorities for patients were how COPD changes over time, the short- and long-term benefits of COPD drug therapy and how to manage the symptoms of COPD. Among patients who selected smoking cessation counselling as an educational priority, 39\% were current smokers. The top three educational priorities for patients as perceived by respiratory specialist physicians were smoking cessation and counselling, how to manage the symptoms of COPD, and how to exercise safely and effectively.

Whereas 23\% of patients believed that their knowledge level about COPD was high, physicians perceived a high knowledge level among only $5 \%$ of their patients. Two specific areas in which gaps existed in perceived knowledge between patients and physicians related to adherence to taking COPD medications and inhaler technique. Eighty-four per cent of patients reported that they rarely or never forgot or missed taking their COPD medications, while physicians believed that $80 \%$ of their patients forgot or missed taking their COPD medications several times per week to several times per month. In terms of inhaler use, $78 \%$ of patients reported that they had very good or good technique, while physicians perceived very good or good technique in only $35 \%$ of their patients. Among health care professionals, patients reported that nurse educators were the most likely to directly observe their inhaler technique (Figure 2). A small percentage of patients $(2 \%)$ responded that they had never been taught proper inhaler technique.

\section{DISCUSSION}

The present study assessed practice patterns and perceptions of COPD among respiratory specialist physicians and their COPD patients in a real-world setting. Patients reported important symptom burden and frequent exacerbations, increasing with disease severity. There was both under- and overprescription of maintenance inhaled therapies according to current clinical practice guidelines. Access to 
nonpharmacological therapies, such as COPD education resources and pulmonary rehabilitation in particular, was low and varied according to region. Perceived knowledge needs and preferred educational resources differed between physicians and patients.

Smoking cessation and counselling was most frequently identified by physicians as an educational priority for their patients. Despite relatively high current smoking rates among patients who participated in the present study, few patients identified this as a perceived knowledge need. Patients wanted to know more about COPD disease progression. Linking these two issues (ie, the role that smoking cessation plays in slowing disease progression) in discussion between patient and health care provider may increase the perceived importance of smoking cessation among patients.

COPD exacerbations were frequent among study patients, which places these patients at a higher risk for future exacerbations (8). The probability of experiencing an exacerbation increased with increasing COPD severity. However, consistent with other studies, even patients with 'mild' disease, regardless of whether assessed using symptoms or spirometry criteria, had experienced recent exacerbations (8). This apparent discrepancy validates aspects of COPD phenotyping suggested in recent COPD clinical practice guidelines - namely, that symptom burden and future risk of exacerbations should be separately assessed and managed in each patient $(1,5)$. This fact, combined with the high prevalence of comorbidities in the study participants, emphasizes the complexity of COPD characterization, which extends beyond simply assessing degree of airflow obstruction by spirometry.

When compared with recommendations in the CTS COPD clinical practice guidelines, potential care gaps were exposed regarding interventions to prevent future COPD exacerbations. Influenza and pneumococcal vaccination rates were suboptimal. The use of a COPD action plan has previously been demonstrated to be most effective in reducing health care utilization related to exacerbations when a written prescription is provided to patients and used in combination with access to a COPD educator (9). However, fewer than $50 \%$ of patients in the present study had a written COPD action plan and only a minority of these patients had access to review this tool with a COPD educator. Furthermore, fewer than $40 \%$ of patients had ever been taught to recognize the signs and symptoms of an exacerbation. For patients at highest risk for future exacerbations, only 34\% were prescribed triple-inhaled maintenance therapy (ie, ICS/LABA plus a long-acting anticholinergic). In contrast to this example of underprescription of COPD medications, there was also evidence of potential overprescription of maintenance inhaled medications in patients with mild disease.

Care gaps may result not only in worsened patient-related outcomes, but also in increased health care costs (10). Although COPD care gaps have been well described in primary care, respiratory specialist physicians are less frequently the target of care gap analysis and subsequent knowledge translation efforts (6). Barriers to adopting current evidence-based knowledge into clinical practice can exist at multiple levels, including the individual practitioner and the health care system (11). More than $90 \%$ of physicians who participated in the present study identified the CTS COPD guidelines as an information resource they referred to in the management of their COPD patients. Lack of knowledge appears unlikely to have been a major barrier to this group of respiratory specialist physicians. Other individual factors, such as lack of time, disagreement with guideline recommendations, forgetfulness or lack of awareness of local resources, may have played a role.

Alternatively, systemic barriers may have dominated as the explanation for the observed potential care gaps. Lack of access to resources was certainly an important factor contributing to underreferral of patients to COPD educators and pulmonary rehabilitation. In addition, there appears to be a need to validate the important role of COPD educators and other educational tools among patients as part of their COPD management strategy. Insurance coverage rules for medications, whether through a public or private system, may have influenced the prescribing patterns of physicians who deviated from evidence-based guidelines. Implementation efforts to narrow the care gaps in COPD will require multifaceted, evidence-based approaches targeting both individual clinicians and systemic barriers (12). The results of the present study help to identify a problem among COPD patients cared for by respiratory specialist physicians, thus warranting the attention of future knowledge translation programs by organizations such as the CTS.

Limitations of the present study include the possibility of selection bias among individuals that chose to participate, resulting in a nonrepresentative selection of Canadian respiratory specialist physicians and their patients. Respiratory physicians with a particular interest in COPD may have been more likely to participate, thus, introducing a self 'selection bias'. This may account for some practice behaviours reported in the present study being better than the perception of 'actual' practice patterns in Canada (eg, use of MRC dyspnea score to rate disease severity, referral rates to pulmonary rehabilitation). It is, therefore, conceivable that rates of potential care gaps may have been even greater without this selection bias. The study methodology did not allow for an independent audit of patient charts. Physicians may have self-reported practice behaviour consistent with guidelines that was different from their actual practice behaviour. The latter limitation would likely have served to bias the results toward an underestimation of the actual care gap. Adherence to guidelines for management decisions, such as pharmacotherapy choices, was assessed based on COPD severity. Recent spirometry results were not always available; however, MRC symptom score was provided for all patients to enable assessment of severity. Finally, the study authors did not return to the study physicians with the results of the analyses to further explore potential barriers to implementation of guideline recommendations in their individual practices.

The present study showed that despite widespread dissemination of COPD clinical practice guidelines, potential care gaps among patients managed by respiratory specialist physicians remain. Differing perceptions about many aspects of COPD among physicians and patients may contribute to these care gaps. Respiratory specialist physicians are another important target group for future knowledge translation interventions. Changes in the health care system will also likely be necessary to bridge the gap between evidence-based clinical knowledge and real-world clinical practice - only then will our COPD patients and society derive maximal benefits from growing scientific knowledge about the management of this disease.

ACKNOWLEDGEMENTS/DISCLOSURES: The authors thank the physicians and patients who participated in this COPD practice assessment. This study was supported by AstraZeneca Canada Inc. Statisticians working at AstraZeneca Canada Inc. undertook the initial data analysis; however, authors had complete access to the data and independently conducted data interpretation. Miriam Banner of inScience Communications, Springer Healthcare provided editing assistance to $\mathrm{PH}$ with the initial draft, funded by AstraZeneca; however, the authors otherwise had complete control and independence over the content and subsequent drafts of the manuscript. All of the listed authors substantially contributed to study design, analysis and interpretation of data, revising the manuscript critically, and providing approval of the submitted version of the manuscript.

CONFLICT OF INTEREST STATEMENTS: Paul Hernandez has participated on medical advisory boards for pharmaceutical companies, as a researcher on industry funded clinical trials, and/or in the development of material and as a speaker for industry funded continuing medical education for the following companies: Actelion, AstraZeneca, Boehringer Ingelheim, CSL Behring, Eli Lilly, GlaxoSmithKline, Merck, Novartis, Nycomed and Pfizer. Meyer Balter has served on medical advisory boards and has received honoraria for speaking and/or contributing to the development of materials to be used for CME programs for the following pharmaceutical companies: AstraZeneca, Boehringer Ingelheim, GlaxoSmithKline, Merck, Novartis, Nycomed and Pfizer. Jean Bourbeau has participated on medical advisory boards, conducted continuing health 
education activities and/or industry-sponsored clinical research trials for the following companies: AstraZeneca, Boehringer Ingelheim, GlaxoSmithKline, Merck, Novartis, Nycomed, Pfizer and Talecris. Charles Chan has served on advisory boards or speaker bureau for the following companies: Abbott, AstraZeneca, Boehringer Ingelheim, GlaxoSmithKline, InterMune, Merck and Pfizer. Darcy Marciniuk has undertaken Consulting or participated on Advisory Boards for the Canadian Lung Association, Health Canada, Health Quality Council, Public Health Agency of Canada, Saskatchewan Medical Association and Saskatoon Health Region. He has received research support (directed to the University of Saskatchewan) from AstraZeneca, Boehringer Ingelheim, Canadian Agency for Drugs and Technology in Health, Canadian Institute of Health Research, GlaxoSmithKline, Forest, Lung Association of Saskatchewan, Novartis, Nycomed, Pfizer, Saskatchewan Health Research Foundation, Saskatchewan Ministry of Health and Schering-Plough. He holds Fiduciary Positions with the Canadian COPD Alliance, American College of Chest Physicians, Chest Foundation, and Lung Association of Saskatchewan; and is an employee of the University of Saskatchewan. Shannon Walker has participated on medical advisory boards for pharmaceutical companies, and/or in the development of material and as a speaker for industry funded continuing medical education for the following companies: AstraZeneca, Boehringer Ingelheim, GlaxoSmithKline, Nycomed and Pfizer.

\section{APPENDIX A PRACTICE PROFILE}

\author{
Program Objectives
}

- To establish the nature of your COPD practices

- To determine current diagnostic, treatment and outcome goals across settings and throughout the country.

- To use the data from the practice assessment to design programs/initiatives to help educate physicians on how to optimize COPD patient outcomes.

\begin{tabular}{|c|c|c|c|}
\hline \multicolumn{4}{|c|}{$\begin{array}{c}\text { Practice Profile } \\
\text { [Answered only once by physician] }\end{array}$} \\
\hline \multicolumn{4}{|c|}{$\begin{array}{l}\text { Please complete the following profile. } \\
\text { You will be asked to enter this data only once. } \\
\text { All responses will be aggregated. } \\
\text { Your personal information will not be passed on for } 3^{\text {rd }} \text { party use. }\end{array}$} \\
\hline & Instructions / Question & Response Options & \begin{tabular}{|l|} 
Response \\
Type
\end{tabular} \\
\hline 1. & $\begin{array}{l}\text { How many years have you been in } \\
\text { specialty practice? }\end{array}$ & $\begin{array}{l}\square<1 \\
\square \quad 1-5 \\
\square \quad 6-10 \\
\square \quad 11-20 \\
\square \quad 21-30 \\
\square>30\end{array}$ & $\begin{array}{l}\text { Drop-down } \\
\text { menu } \\
\text { Single choice }\end{array}$ \\
\hline 2. & $\begin{array}{l}\text { How many years of post-graduate } \\
\text { training did you complete (after } \\
\text { graduating as an MD)? }\end{array}$ & $\begin{array}{ll}\square & <3 \\
\square & 3 \\
\square & 4 \\
\square & 5 \\
\square & 6 \\
\square & 7 \\
\square & >7\end{array}$ & \begin{tabular}{|l|} 
Drop-down \\
menu \\
Single choice
\end{tabular} \\
\hline 3. & $\begin{array}{l}\text { What best describes your practice } \\
\text { setting? }\end{array}$ & \begin{tabular}{|l}
$\square \quad$ University/Hospital - full-time \\
practice \\
$\square \quad$ University/Hospital part-time, \\
private practice part-time \\
$\square \quad$ Non-university/hospital - private \\
clinic practice \\
$\square \quad$ Community practice \\
\end{tabular} & \begin{tabular}{|l} 
Drop-down \\
menu \\
Single choice
\end{tabular} \\
\hline 4. & Is this a solo or group practice? & $\begin{array}{ll}\square \text { Solo } \\
\square \text { Group }\end{array}$ & \begin{tabular}{|l|} 
Drop-down \\
menu \\
Single choice
\end{tabular} \\
\hline 5. & $\begin{array}{l}\text { How many hours per week do you } \\
\text { spend with patients (all } \\
\text { diagnoses)? }\end{array}$ & 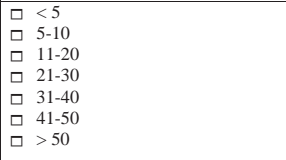 & \begin{tabular}{|l} 
Drop-down \\
menu \\
Single choice
\end{tabular} \\
\hline 6. & What is your referral population? & 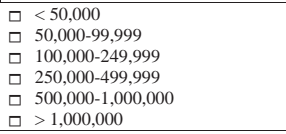 & $\begin{array}{l}\text { Drop-down } \\
\text { menu } \\
\text { Single choice }\end{array}$ \\
\hline
\end{tabular}

\begin{tabular}{|c|c|c|c|c|}
\hline 7. & $\begin{array}{l}\text { What is generally the average wait } \\
\text { time to see a patient? }\end{array}$ & $\begin{array}{l}\square \\
\square \\
\square \\
\square \\
\square \\
\square \\
\square \\
\square \\
\square\end{array}$ & $\begin{array}{l}<1 \text { week } \\
1-2 \text { weeks } \\
3-4 \text { weeks } \\
5 \text { weeks to } 2 \text { months } \\
3-4 \text { months } \\
5-6 \text { months } \\
7-9 \text { months } \\
10-12 \text { months } \\
>12 \text { months }\end{array}$ & \begin{tabular}{|l|} 
Drop-down \\
menu \\
Single choice
\end{tabular} \\
\hline 8. & $\begin{array}{l}\text { In your practice what is the } \\
\text { average wait time to see a COPD } \\
\text { patient? }\end{array}$ & $\begin{array}{l}\square \\
\square \\
\square \\
\square \\
\square \\
\square \\
\square \\
\square\end{array}$ & $\begin{array}{l}<1 \text { week } \\
1-2 \text { weeks } \\
3-4 \text { weeks } \\
5 \text { weeks to } 2 \text { months } \\
3-4 \text { months } \\
5-6 \text { months } \\
7-9 \text { months } \\
10-12 \text { months } \\
>12 \text { months }\end{array}$ & \begin{tabular}{|l|} 
Drop-down \\
menu \\
Single choice
\end{tabular} \\
\hline 9. & $\begin{array}{l}\text { How many patients diagnosed } \\
\text { with COPD do you have in your } \\
\text { practice who you are actively } \\
\text { following? (Active = seen in the } \\
\text { last year) }\end{array}$ & $\begin{array}{l}\square \\
\square \\
\square \\
\square \\
\square\end{array}$ & $\begin{array}{l}<50 \\
50-99 \\
100-500 \\
>500 \\
\text { Not sure }\end{array}$ & \begin{tabular}{|l|} 
Drop-down \\
menu \\
Single choice
\end{tabular} \\
\hline 10. & $\begin{array}{l}\text { What assessments do you } \\
\text { routinely perform to assess new } \\
\text { COPD patients? (Check all that } \\
\text { apply) }\end{array}$ & & $\begin{array}{l}\text { Spirometry } \\
\text { Physical exam, including } \mathrm{Sp}_{2} \\
\text { Chest radiograph } \\
\text { Pulmonary function test } \\
\text { Arterial blood gas }\end{array}$ & $\begin{array}{l}\text { Drop-down } \\
\text { menu } \\
\text { Multiple } \\
\text { choice }\end{array}$ \\
\hline 11. & $\begin{array}{l}\text { What assessments do you } \\
\text { routinely perform to assess follow- } \\
\text { up COPD patients? (Check all that } \\
\text { apply) }\end{array}$ & $\begin{array}{l}\square \\
\square \\
\square \\
\square\end{array}$ & $\begin{array}{l}\text { Spirometry } \\
\text { Physical exam, including } \mathrm{Sp}_{2} \\
\text { Chest radiograph } \\
\text { Pulmonary function test }\end{array}$ & $\begin{array}{l}\text { Drop-down } \\
\text { menu } \\
\text { Multiple } \\
\text { choice }\end{array}$ \\
\hline 12. & $\begin{array}{l}\text { When assessing/managing your } \\
\text { COPD patients which, if any, of } \\
\text { the clinical guidelines do you refer } \\
\text { to? Check all that apply }\end{array}$ & & $\begin{array}{l}\text { CTS (Canadian Thoracic Society) } \\
\text { ATS/ERS (American Thoracic } \\
\text { Society/European Respiratory } \\
\text { Society) } \\
\text { GOLD (Global Initiative for Chronic } \\
\text { Obstructive Lung Disease) } \\
\text { BTS (British Thoracic Society) } \\
\text { None of the above }\end{array}$ & Multi-select \\
\hline 13. & $\begin{array}{l}\text { How frequently do you use the } \\
\text { Medical Research Council (MRC) } \\
\text { dyspnea scale when assessing } \\
\text { patients with respiratory problems/ } \\
\text { difficulty breathing? }\end{array}$ & $\begin{array}{l}\square \\
\square \\
\square \\
\square\end{array}$ & $\begin{array}{l}\text { Always } \\
\text { Frequently } \\
\text { Rarely } \\
\text { Never }\end{array}$ & \begin{tabular}{|l|} 
Single-select \\
\end{tabular} \\
\hline 14. & $\begin{array}{l}\text { Rank the frequency that the } \\
\text { following factors influence your } \\
\text { treatment plan for your COPD } \\
\text { patients? Please rank your top } \\
\text { three only. ( } 1 \text { being most frequent) }\end{array}$ & $\begin{array}{l}\square \\
\square \\
\square \\
\square \\
\square \\
\square \\
\square \\
\square \\
\square \\
\square \\
\square\end{array}$ & $\begin{array}{l}\text { Adverse events } \\
\text { Convenience/compliance } \\
\text { Lack of effect } \\
\text { Device preference: Patient } \\
\text { Stage of disease } \\
\text { Patient's age } \\
\text { Comorbidities } \\
\text { Results of clinical trials } \\
\text { Symptom occurrence } \\
\text { Reimbursement } \\
\text { COPD Guidelines } \\
\text { Personal experience (own practice) }\end{array}$ & Rank (top 3) \\
\hline 15. & $\begin{array}{l}\text { How knowledgeable do you feel } \\
\text { your patients are about their } \\
\text { COPD medications? } \\
\text { (corresponds with question in } \\
\text { patient survey) Q5 of patient } \\
\text { questionnaire }\end{array}$ & $\begin{array}{l}\square \\
\square \\
\square\end{array}$ & $\begin{array}{l}\text { Low level of knowledge } \\
\text { Moderate level of knowledge } \\
\text { High level of knowledge }\end{array}$ & \\
\hline 16. & $\begin{array}{l}\text { In general, at what time of the day } \\
\text { do patients find their symptoms to } \\
\text { be the most challenging? } \\
\text { (corresponds with question in } \\
\text { patient survey) Q3 of patient } \\
\text { questionnaire }\end{array}$ & & $\begin{array}{l}\text { Morning } \\
\text { Mid-day } \\
\text { Afternoon } \\
\text { Evening } \\
\text { Night } \\
\text { Not sure }\end{array}$ & \begin{tabular}{|l|} 
Single-select \\
\end{tabular} \\
\hline 17. & \begin{tabular}{l|} 
On average, how well do your \\
patients utilize their inhaler \\
device? \\
(corresponds with question in \\
patient survey) Q6 of patient \\
questionnaire \\
\end{tabular} & ㅁ & $\begin{array}{l}\text { Very good technique } \\
\text { Good technique } \\
\text { Average technique } \\
\text { Poor Technique }\end{array}$ & Single-select \\
\hline 18. & $\begin{array}{l}\text { How often do you believe your } \\
\text { COPD patients forget, or miss } \\
\text { taking their medications? } \\
\text { (corresponds with question in } \\
\text { patient survey) Q7 of patient } \\
\text { questionnaire }\end{array}$ & $\begin{array}{l}\square \\
\square \\
\square \\
\square\end{array}$ & $\begin{array}{l}\text { Never } \\
\text { Very rarely } \\
\text { Several times a month } \\
\text { Several times a week } \\
\text { Everyday }\end{array}$ & \\
\hline 19. & $\begin{array}{l}\text { How do you educate your patients } \\
\text { about COPD? Check all that apply } \\
\text { (corresponds with question in } \\
\text { patient survey) Q9 of patient } \\
\text { questionnaire }\end{array}$ & $\square$ & $\begin{array}{l}\text { Discuss during visit } \\
\text { COPD Educator (nurse, ERT, etc.) - } \\
\text { Nurse counsellling in patient } \\
\text { questionnaire } \\
\text { Provide written handouts } \\
\text { Recommend websites } \\
\text { COPD Society materials - not in } \\
\text { patient questionnaire but in patient } \\
\text { questionnaire "COPD Patient Group" } \\
\text { is an option } \\
\text { Searching internet } \\
\text { Family, friends, neighbours } \\
\text { Other } \\
\text { Did not learn about COPD yet }\end{array}$ & \\
\hline 20. & $\begin{array}{l}\text { Pick the top } 3 \text { areas you feel are } \\
\text { the most important to discuss with } \\
\text { your patients } \\
\text { (corresponds with question in } \\
\text { patient survey). Q11 of patient } \\
\text { questionnaire }\end{array}$ & & $\begin{array}{l}\text { How COPD changes over time } \\
\text { The short and long-term benefits of } \\
\text { COPD drug therapy } \\
\text { How to manage the symptoms of } \\
\text { COPD } \\
\text { The various drug therapies available } \\
\text { Smoking cessation counseling } \\
\text { How to exercise safely and } \\
\text { effectively } \\
\text { End of life/advance care planning }\end{array}$ & Multi-select \\
\hline
\end{tabular}




\section{APPENDIX B}

PRACTICE ASSESSMENT IN COPD

Thank you for volunteering to answer some questions concerning your COPD. We will be presenting the combined responses to these questions to a group of physicians who are developing an educational program to help physicians better treat and manage patients with COPD. Please note that your responses are completely confidential and at no time will you be identified in this program. Your responses will NOT be seen by your physician at any time as you will place this form into the envelope provided. Your responses will be grouped with those of other patients from across Canada for the purpose of Continuing Education.

Please be sure to fill the bubbles in completely for the options you select:

\section{Below are some questions related to how you feel at this moment:}

1. How does shortness of breath impact your ability to complete daily living activities e.g. meal preparation, bathing, dressing etc.? (Select one)

O Not at all O A little O Moderately O Very much O Extremely

2. Regarding daily living activities, how often does your physician ask about what time of day your COPD is most challenging for you? (Select one)

O Never O Rarely O Sometimes O Often O Very Often

3. In general, at what time of day do you find your symptoms to be the most troublesome? (Select one)

O Morning O Mid-day O Afternoon O Evening O Night O Not sure

\section{Below are some questions related to your knowledge of COPD and the medication you are taking:}

4. How long have you been taking a prescription medication to control your COPD? (Select one)

O Less than 6 months 0 6-12 months 01 year to 2 year 11 months O 3-5 years O More than 5 years

5. How knowledgeable do you feel about your COPD medications? (Select one)

O Low level of knowledge

O Moderate level of knowledge

O High level of knowledge

6. On average, how well do you think you use your inhaler device? (Select one)

O Very good technique

O Good technique

O Average technique

O Poor technique

7. How often do you forget, or miss taking your COPD medications? (Select one)

O Never

O Very rarely

O Several times a month

O Several times a week

O Everyday

8. On average, how often do you see your physician/respirologist for your COPD condition? (Select one)

$O$ Less than once per year

O 1-2 times per year

O 3-6 times per year

O 6-10 times per year

O More than 10 times per year

9. How do you learn more about COPD? (Select all that apply)

O Physician discusses

O Nurse counseling

O Physician/team provides

O Physician/team recommends during visit

O Written handouts

O Websites

O COPD Patient Group
O Searching the internet

O Family, friend, or neighbour

O Other

O Did not learn about COPD yet

10. How were you taught to use your COPD medications? (Select all that apply)

O Told by my Doctor

O Shown by my Doctor

O Told by a Nurse Educator

O Shown by a Nurse Educator

O The Doctor watched me use it correctly

O A Nurse educator watched me use it correctly

O Told by my pharmacist

O Shown by my pharmacist

O Other

O Never taught

11. Select the top 3 areas where you would like to receive more information.

O How COPD changes over time

O How to manage COPD symptoms

$\mathrm{O}$ The short and long-term benefits of COPD drug therapy

O Various drug therapies

O Smoking cessation counseling

O How to exercise safely and effectively

O End-of-life/advanced care planning

12. Have you been taught to recognize the signs of an exacerbation (i.e. symptom worsening, increase of medication, hospitalization) of your COPD?

O Yes, by my doctor

$\mathrm{O}$ Yes, by a nurse educator

$\mathrm{O}$ No

13. Do you currently have a plan of action to self-manage exacerbations?

$\mathrm{O}$ Yes

O No

\section{If you do not have an action plan, please skip questions 14-16}

14. Regarding your action plan, please select one of the two options below:

O Discussed with healthcare provider and written down

O Discussed with healthcare provider and not written down

15. Do you also have a prescription for antibiotics or prednisone that you can fill when needed?

O Yes

O No

16. Does your action plan include access to a case manager (i.e. $\mathrm{O}$ Yes respiratory therapist, nurse)?

O No

17. Have you participated in a pulmonary rehab program?

O Yes

O No

O Not sure what this is

18. Who referred you to pulmonary rehab?

O Respirologist

O Family Physician

O Respiratory Therapist

O Nurse

O Another patient

O Website

O Other healthcare professional

O Other

Please, return this form to Isis Healthcare (3365 Harvester Road, 2nd Floor, Burlington, ON L7N 3N2) in the prepaid envelope provided. 


\section{APPENDIX C PAC ASSESSMENT FLOW}

Program Objectives

Provide specialists with an opportunity to capture trends within their daily practice through a series of prospective patient assessments

Enable specialists to compare and review their data against the aggregate practice of their peers, resulting in an opportunity to analyze and identify perceptions of practice versus what actually occurs

口 Enable specialists to identify possible areas of improvement in patient management and patient quality of life

\section{PAC Assessment Flow}

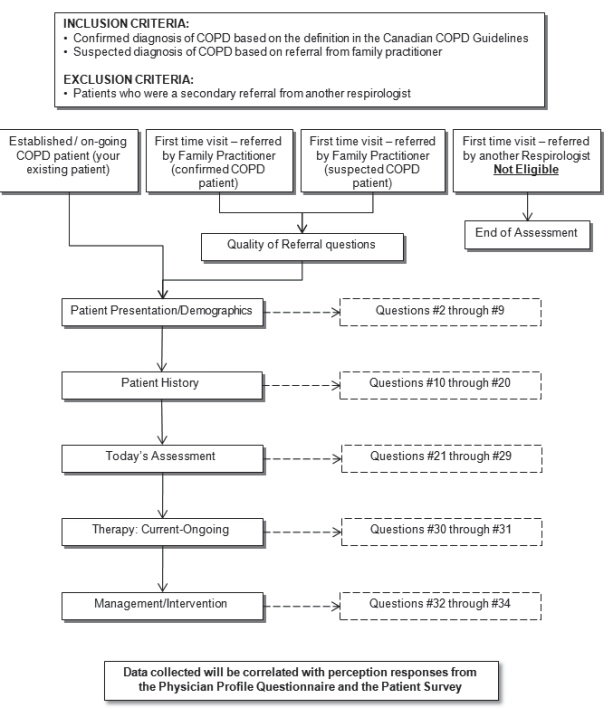

\begin{tabular}{|c|c|c|c|}
\hline \multicolumn{4}{|c|}{ COPD Patient Assessment } \\
\hline \multicolumn{4}{|c|}{ 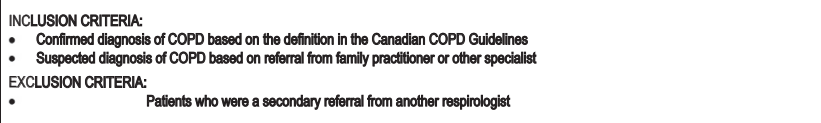 } \\
\hline & Instructions / Question & Response Options & Response Type \\
\hline 1) & Clinic visit: & 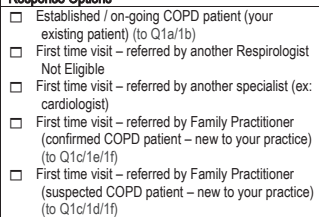 & $\begin{array}{l}\text { Drop down menu } \\
\text { Single choice }\end{array}$ \\
\hline & 1.a When did you see this patient last? & 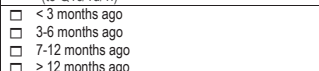 & \begin{tabular}{|l|} 
Drop-down menu \\
Single choice
\end{tabular} \\
\hline & 1.b How long have you been treating this patient? & $\begin{array}{l}\square<1 \text { year } \\
\square \quad 1-2 \text { years } \\
\square \quad 3-5 \text { years } \\
\square \quad 6-10 \text { years } \\
\square \quad 11-15 \text { years } \\
\square \quad>15 \text { years }\end{array}$ & \begin{tabular}{|l|} 
Drop down menu \\
Single choice
\end{tabular} \\
\hline & $\begin{array}{l}\text { 1.c In your opinion, was the referral from the FP } \\
\text { complete? }\end{array}$ & ㅁ Yes & Single-select \\
\hline & $\begin{array}{l}\text { 1.d What criteria were used by the FP to establish } \\
\text { a suspicion of COPD (oheck all that applyy) }\end{array}$ & $\begin{array}{l}\text { Screening questionnaire (30 second COPD Test) } \\
\text { Medical Research Council dyspnea scale? (MRC) } \\
\text { Spirometry (pre-bronchodilator) } \\
\text { Spiriometry (post-bronchodiliator) } \\
\text { Historylexam } \\
\text { Other } \\
\end{array}$ & Multi-select \\
\hline & $\begin{array}{l}\text { 1.e In addition to spirometry, what criteria was } \\
\text { used by the FP to establish a diagnosis of COPD }\end{array}$ & $\begin{array}{l}\text { Full Pulmonary function test not available } \\
\text { Spirometry not done }\end{array}$ & Multi-select \\
\hline & $\begin{array}{l}\text { 1.f Do you feel this patient could have benefitted } \\
\text { from earlier detection? }\end{array}$ & \begin{tabular}{|ll}
$\square$ & Yes \\
$\square$ & Possibly \\
$\square$ & No
\end{tabular} & \\
\hline 2) & \begin{tabular}{|l} 
Patient age: \\
\end{tabular} & & Number pad \\
\hline 3) & Gender: & \begin{tabular}{|l|l|} 
Male \\
$\square$ Female
\end{tabular} & \begin{tabular}{|l|} 
Single choice \\
\end{tabular} \\
\hline 4) & Height & $\square$ & \begin{tabular}{|l|}
$\begin{array}{l}\text { Slider (and } \\
\text { conversion to pounds) }\end{array}$ \\
\end{tabular} \\
\hline 5) & Weight & $\square$ & $\begin{array}{l}\text { Slider (and } \\
\text { conversion to } \\
\text { centimeters) }\end{array}$ \\
\hline 6) & Smoking status & $\begin{array}{ll}\square & \text { Current Smoker (to Q6a) } \\
\square \quad \text { Past Smoker (to Q6a) } \\
\square \quad \text { Non-Smoker }\end{array}$ & \begin{tabular}{|l|} 
Single-select \\
\end{tabular} \\
\hline & $\begin{array}{l}\text { 6.a How many pack years has/did this patient } \\
\text { smoke(d)? }\end{array}$ & \# & \begin{tabular}{|l} 
Number pad (1 to 99) \\
\end{tabular} \\
\hline 7) & $\begin{array}{l}\text { Family history for COPD } \\
\end{array}$ & $\begin{array}{|ll|}\square & \text { Yes } \\
\square & \text { No } \\
\square & \text { Don't know } \\
\end{array}$ & Single-select \\
\hline 8) & Employment status & $\begin{array}{l}\text { W Working - Full time } \\
\text { W Working - Modified work due to COPD } \\
\text { ㄴemployed - Quitllost work due to COPD } \\
\text { Retired } \\
\text { None of the above }\end{array}$ & \begin{tabular}{|l} 
Single-select \\
\end{tabular} \\
\hline
\end{tabular}

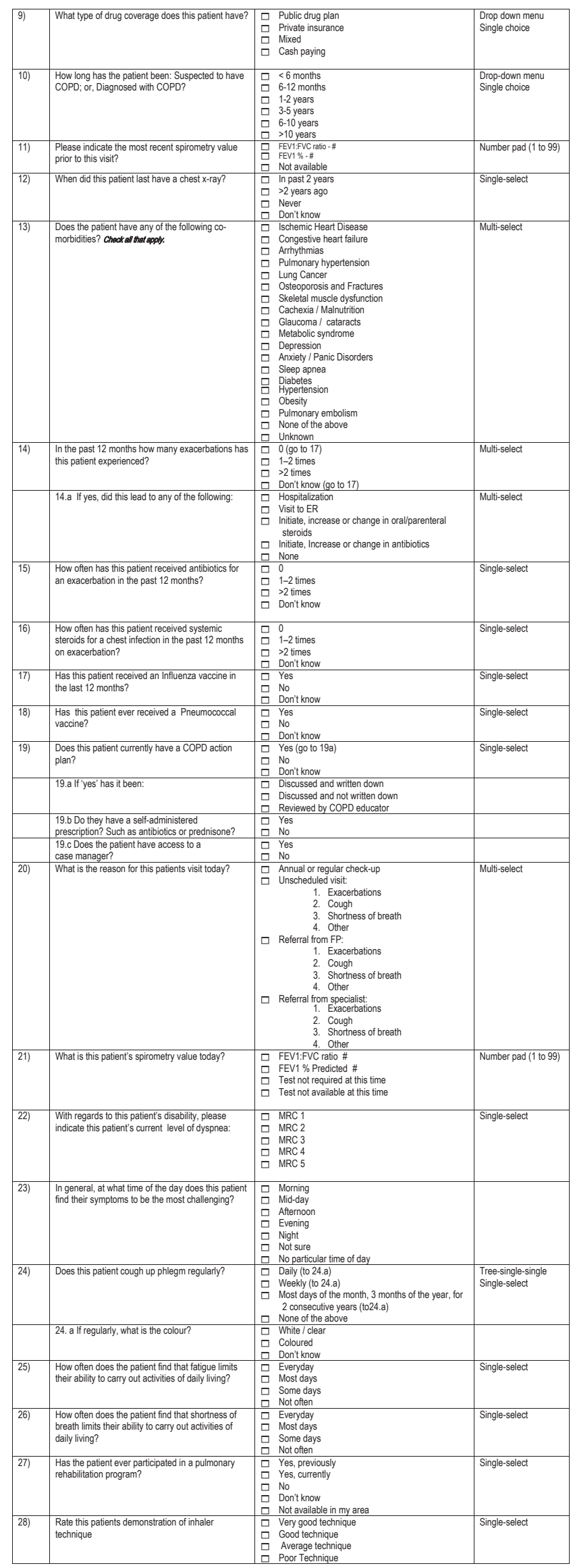




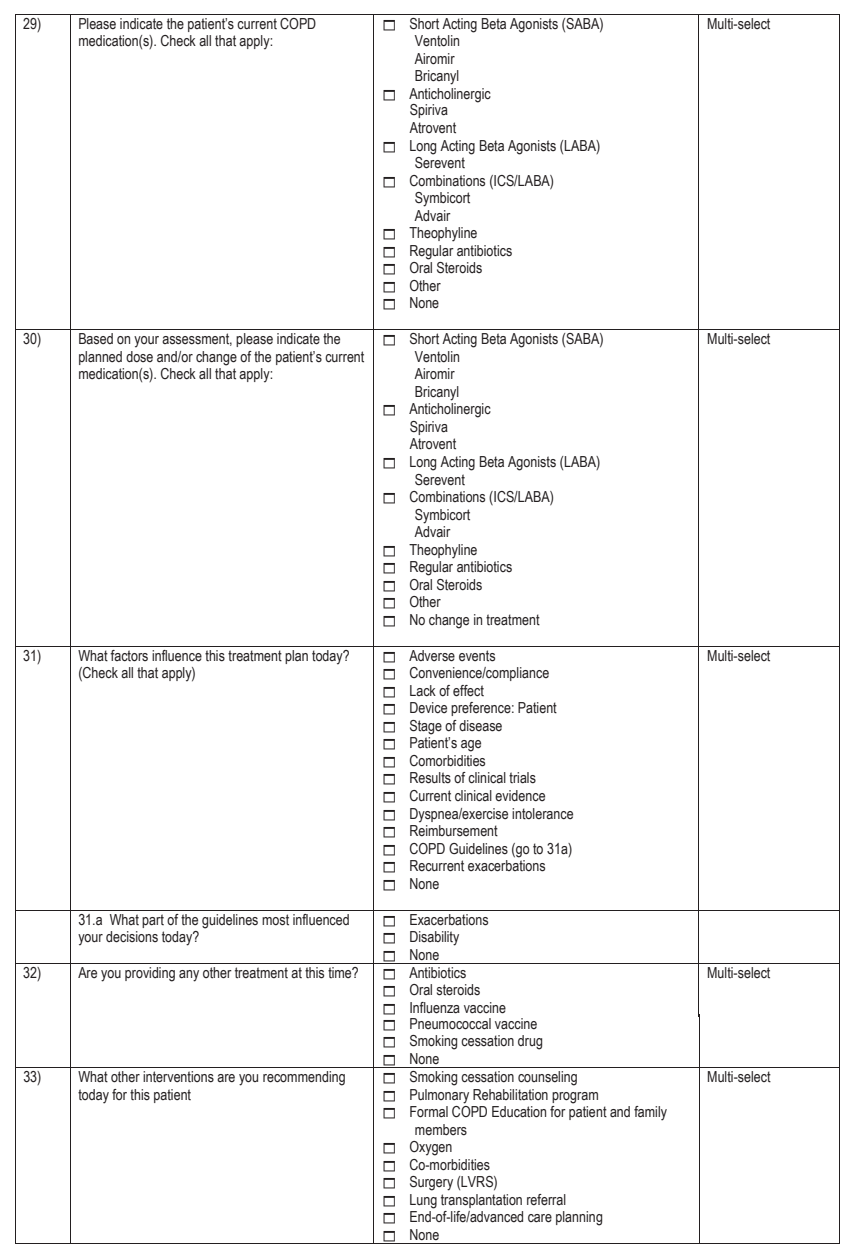

\section{REFERENCES}

1. O'Donnell DE, Hernandez P, Kaplan A, et al. Canadian Thoracic Society recommendations for management of chronic obstructive pulmonary disease - 2008 update - highlights for primary care. Can Respir J 2008;(15 Suppl A):1A-8A.

2. Respiratory Disease in Canada. <www.phac-aspc.gc.ca/publicat/ rdc-mrc01/pdf/rdc0901e.pdf> (Accessed December 4, 2007).

3. Hill K, Goldstein RS, Guyatt GH, et al. Prevalence and underdiagnosis of chronic obstructive pulmonary disease among patients at risk in primary care. CMAJ 2010;182:673-8.

4. Celli B, MacNee W, Agusti A, et al. Standards for the diagnosis and treatment of patients with COPD: A summary of the ATS/ ERS position paper. Eur Respir J 2004;23:932-46.

5. Global strategy for the diagnosis, management and prevention of Chronic Obstructive Pulmonary Disease (revised 2011). Global initiative for chronic Obstructive Lung Disease (GOLD). $<$ www.goldcopd.com> (Accessed February 29, 2012).

6. Bourbeau J, Sebalt RJ, Day A, et al. Practice patterns in the management of COPD in primary practice: The CAGE study. Can Respir J 2008;15:13-19.

7. Hernandez P, Balter M, Bourbeau J, Hodder R. Living with COPD: A survey of patients' knowledge and attitudes. Respir Med 2009;103:1004-12.

8. Hurst JR, Vestbo J, Anzueto A, et al. Susceptibility to exacerbation in chronic obstructive pulmonary disease. N Engl J Med 2010;363:1128-38.

9. Bourbeau J, Julien M, Maltais F, et al. Reduction of hospital utilization in patients with chronic obstructive pulmonary disease: A disease-specific self-management intervention. Arch Intern Med 2003;163:585-91.

10. Asche CV, Leader S, Plauschinat C, et al. Adherence to current guidelines for chronic obstructive pulmonary disease (COPD) among patients treated with combination of long-acting bronchodilators or inhaled corticosteroids. Int J COPD 2012;7:201-9.

11. Grimshaw J, Eccles M, Tetro J. Implementing clinical guidelines: Current evidence and future implications. J Contin Educ Health Prof 2004;(24 Suppl 1):S31-7.

12. Graham ID, Logan J, Harrison MB, et al. Lost in translation: Time for a map? J Contin Educ Health Prof 2006;26:13-24. 


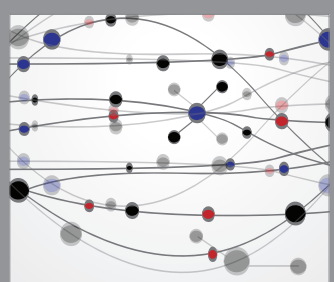

The Scientific World Journal
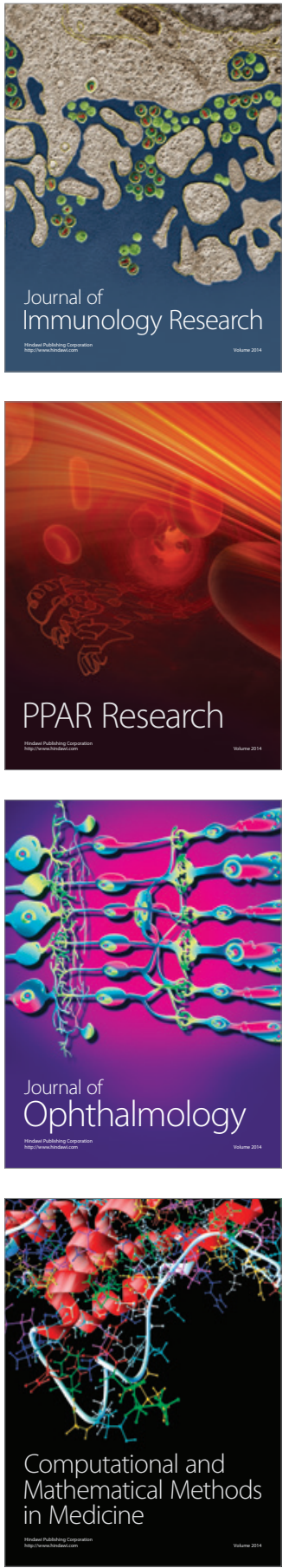

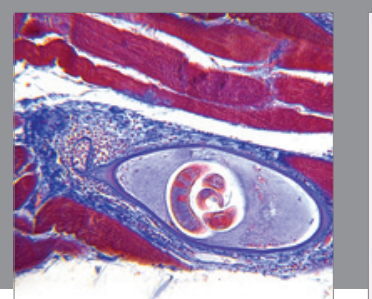

Gastroenterology Research and Practice

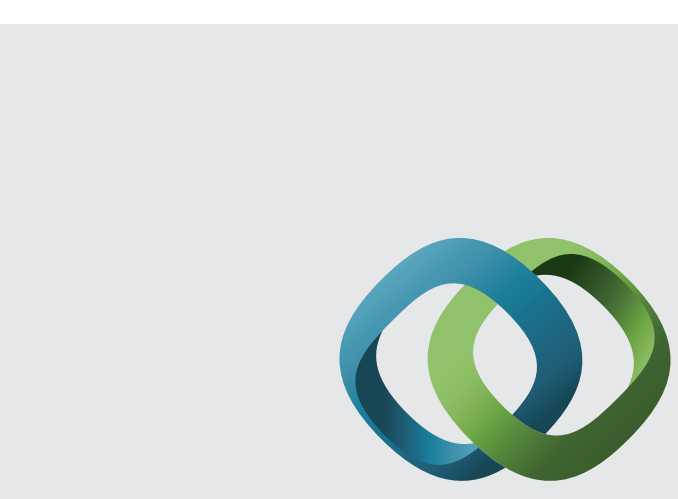

\section{Hindawi}

Submit your manuscripts at

http://www.hindawi.com
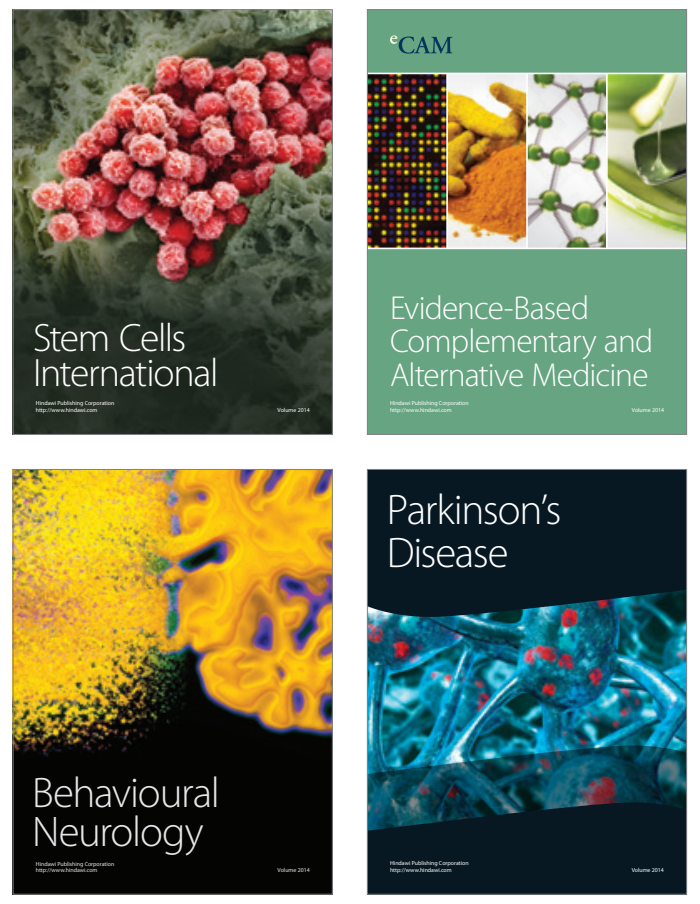
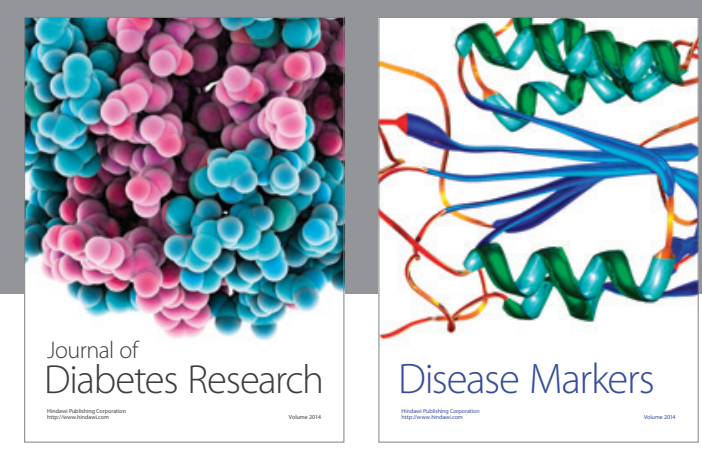

Disease Markers
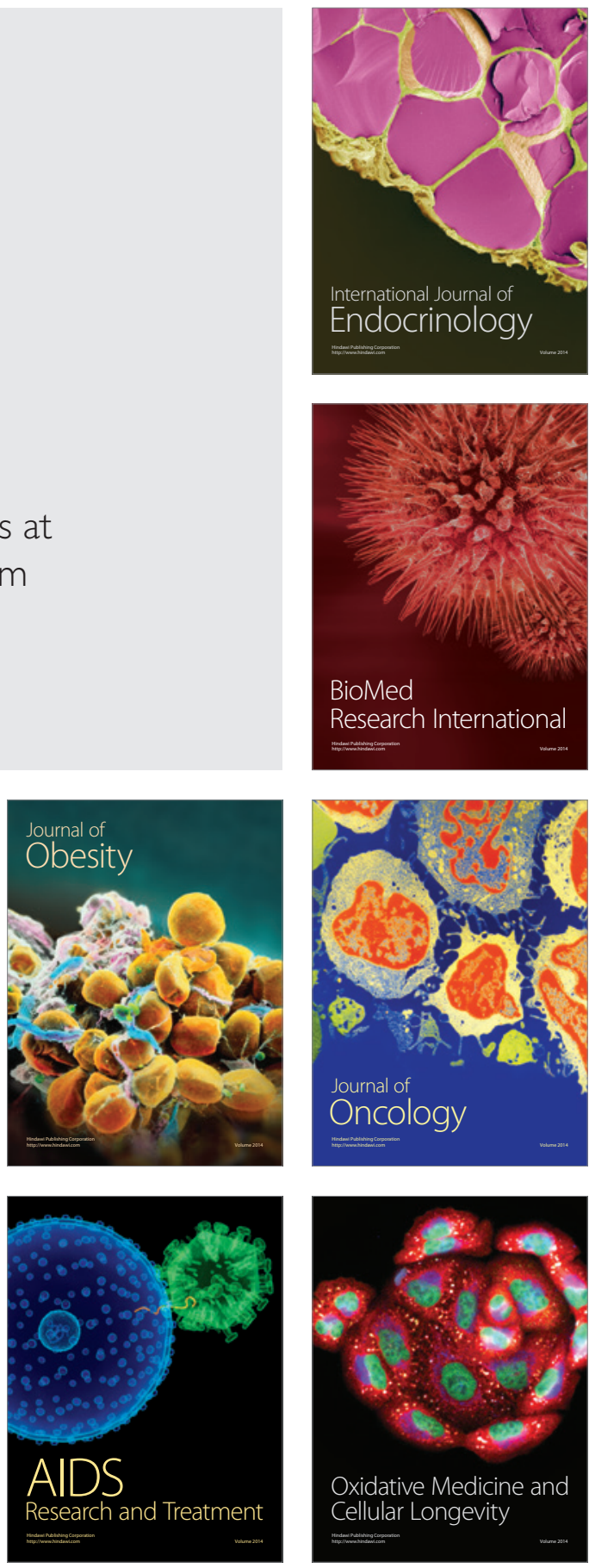